\title{
Stakeholder-Driven Strategic Renewal
}

\author{
Megan F. Hess ${ }^{1} \&$ Andrew M. Hess ${ }^{1}$ \\ ${ }^{1}$ Williams School of Commerce, Economics, and Politics, Washington and Lee University, USA \\ Correspondence: Megan F. Hess, School of Commerce, Economics, and Politics, Washington and Lee University, \\ 204 W. Washington St. Lexington, VA 24450, USA. Tel: 540-458-8370. E-mail: hessm@ wlu.edu
}

Received: December 10, 2015

Accepted: January 25, 2016

Online Published: February 25, 2016

doi: 10.5539/ibr.v9n3p53

URL: http://dx.doi.org/10.5539/ibr.v9n3p53

\begin{abstract}
In an ever-changing global marketplace, organizations must adapt and renew to survive. To achieve such strategic renewal, however, organizations must overcome the inertial forces of existing competencies to evolve and develop new ones. Drawing on relational and behavioral theory, we describe how three aspects of stakeholder relationship management-employee alertness, openness to change, and knowledge exchange-both facilitate the exploration activities necessary for strategic renewal and avert the behavioral tendency toward strategic inertia. Our analysis of stakeholder-driven strategic renewal not only extends and elaborates the concept of stakeholder relationship management by making explicit its connections to strategic renewal, but it also highlights the importance of the proper fit between employee roles and dispositions in shaping the effectiveness of the managing for stakeholders approach.
\end{abstract}

Keywords: stakeholder relationship management, strategic renewal, stakeholder theory, behavioral theory

\section{Introduction}

Organizations today must be nimble to survive the pressures of an increasingly complex global marketplace. Strategies that focus merely on quality, productivity, and efficiency are no longer sufficient to enable the long-term success of the enterprise. Instead, organizations also need to be entrepreneurial and look for ways to create, shape, and respond to opportunities in the external environment. In short, organizations must engage in strategic renewal, a process of overcoming the inertial forces of existing competencies to evolve and develop new ones (Doz, 1996; Huff, J., Huff, A., \& Thomas, 1992; Floyd \& Lane, 2000; Johnson, 1988). Current theories of strategic renewal propose that success depends upon the firm's ability to exploit existing core competencies while also exploring new ones (Floyd \& Lane, 2000, p. 155). However, a behavioral understanding of the firm suggests that achieving strategic renewal may be challenging, since employees' natural tendency is to focus on exploiting current competencies at the expense of exploring and developing new ones (Levinthal \& March, 1993; March, 1991).

Past treatments of strategic renewal in the literature highlight many pathways for achieving renewal, including new product development, investments in research and development, changes in staffing and hiring practices, corporate venturing and acquisitions, and reorganizations (e.g., Agarwal \& Helfat, 2009; Crossan \& Berdrow, 2003; He \& Wong, 2004; Hess \& Rothaermel, 2011). In this paper, we elaborate a different approach for strategic renewal, one that is grounded in the principles of stakeholder relationship management. Stakeholder relationship management, also called "managing for stakeholders," is a strategic approach to transacting with organizational stakeholders (customers, suppliers, investors, employees, regulators, community leaders, etc.) wherein the focal firm attempts to understand and give voice to stakeholder concerns, to prioritize the development of long-term relationships with stakeholders, and to seek positive sum solutions wherein multiple stakeholders benefit simultaneously (Agle et al., 2008; Freeman, Harrison, \& Wicks, 2007; Harrison, Bosse, \& Phillips, 2010).

Scholars and practitioners alike have long recognized the important role that stakeholder relationship management plays in exploiting a firm's core competencies by lowering transaction costs, increasing efficiencies, reducing risk, and enhancing employee engagement (see Clement, 2005 for a review). However, relatively few scholars have considered the role that stakeholder relationship management may also play in facilitating the exploration activities necessary for strategic renewal (Kuratko, Hornsby, \& Goldsby, 2007). We believe that the connections between stakeholder relationship management and strategic renewal merit further examination from both academics and practitioners. In particular, the extant literature has paid little attention to the role of individuals in fostering renewal through the stakeholder relationship management process (McVea \& Freeman, 
2005).

Drawing upon the relational view (e.g., Dyer \& Singh, 1998) and behavioral theory (e.g., Cyert \& March, 1963), we propose a framework for stakeholder-driven strategic renewal that specifies both how stakeholder relationship management encourages the exploratory activities necessary for strategic renewal and who plays a role in this process. We propose that stakeholder-driven strategic renewal is a process of alertness, openness to change, and knowledge exchange that facilitates the core strategic renewal activities of learning, collaborating, and creating opportunities in the organizational environment. By exploring this process of stakeholder-driven strategic renewal and further identifying its boundary conditions, this paper makes several theoretical contributions. First, we offer a more relational perspective on strategic renewal, suggesting that stakeholder relationship management offers a more cooperative approach to renewal in lieu of the threat-based logic of other strategic frameworks (e.g., Mitchell, Agle, \& Wood, 1997; Porter, 1980). We also specify the mechanisms by which stakeholder relationship management activities can help overcome the behavioral tendency towards myopia and strategic inertia and facilitate strategic renewal. In doing so, we also explicitly consider the role of human capital in fostering strategic renewal (Kang, Morris, \& Snell, 2007; Lubatkin, Simsek, Ling, \& Veiga, 2006). Our analysis of stakeholder-driven strategic renewal thus not only extends and elaborates the concept of stakeholder relationship management by making explicit its connections to strategic renewal, but it also highlights the importance of the proper fit between employee roles and dispositions in shaping the effectiveness of the managing for stakeholders approach.

\section{Literature Review}

We build upon two streams within the management literature to develop our framework: Strategic renewal and stakeholder relationship management. By integrating these perspectives, we highlight both the behavioral challenges of strategic renewal and the relational benefits of stakeholder relationship management.

\subsection{The Challenge of Strategic Renewal}

Strategic renewal represents the processes through which an organization attempts to refresh or renew key attributes, capabilities, or resources (Floyd \& Lane, 2000). Current treatments of strategic renewal propose that success depends upon the firm's ability to achieve organizational ambidexterity; that is, to exploit existing core competencies while also exploring new ones (Floyd \& Lane, 2000; O'Reilly \& Tushman, 2008). Developing the capability for organizational ambidexterity is not without its challenges, however. Exploration and exploitation activities are fundamentally different, requiring different norms, structures, and skills (Tushman \& O'Reilly, 1996). As O’Reilly and Tushman (2008, p. 189) note, "exploitation is about efficiency, increasing productivity, control, certainty, and variance reduction. Exploration is about search, discovery, autonomy, innovation, and embracing variation." To help balance these radically different dimensions of strategic renewal, some scholars have explored structural and process approaches (see Tushman, Smith, Wood, Westerman, \& O'Reilly, 2010 for a review), whereas others have looked to the role of individuals, especially those in leadership positions (Floyd \& Lane, 2000; Lubatkin et al., 2006; Smith \& Tushman, 2005).

Recent interest in the roles that individuals play in the process of strategic renewal reflects a behavioral understanding of the challenge of strategic renewal. Scholars have observed that employees have a tendency to focus on exploiting current competencies at the expense of exploring and developing new ones (e.g., Levinthal \& March, 1993; March, 1991). Only when employees recognize a disparity between the firm's current capabilities and those needed to fit within a changing business environment will they be motivated to explore new approaches (Simsek, Lubatkin, \& Floyd, 2003). Such employee perceptions of the need for change may be limited, however. Resistance to change has been modeled as a phenomenon of escalating commitment to past courses of action (Staw, 1981) and a dominant response to uncertainty in the environment (Staw, Sandelands, \& Dutton, 1981). Others have noted that cognitive coping mechanisms such as schemas, heuristics, and biases limit employee perceptions, narrow the search for information, and cause employees to repeat past mistakes (Bateman \& Zeithaml, 1989; Cyert \& March, 1963; March \& Shapira, 1987; Walsh, 1995).

While many in strategic management have considered this problem, few have explored the role of employee-stakeholder relationships in overcoming the behavioral limitations that lead to strategic inertia and myopia. Viewing strategic renewal from the relational perspective highlights new opportunities and threats for organizational dynamism (Ghoshal \& Moran, 1996). As summarized in Table 1, a relational understanding of strategic renewal treats stakeholders as heterogeneous individuals rather than homogenous groups, it emphasizes social capital over financial capital, it illuminates opportunities for collaboration and engagement, and it suggests that effective governance mechanisms can evolve organically based on norms of reciprocity. 
Table 1. Contrasting views of strategic renewal

\begin{tabular}{|c|c|}
\hline Traditio & elational View \\
\hline $\begin{array}{l}\text { Level of analysis: Emphasis on the organizational level, treating } \\
\text { stakeholders as homogeneous groups }\end{array}$ & $\begin{array}{l}\text { - Level of analysis: Emphasis on relationships, treating } \\
\text { stakeholders as heterogeneous individuals }\end{array}$ \\
\hline Resources: Emphasis o & - $\quad$ Resources: Emphasis on social capital \\
\hline Opportunity: Stakeholder preferences must be discerned & $\begin{array}{l}\text { - Opportunity: Stakeholder preferences can be co-created and } \\
\text { shaped }\end{array}$ \\
\hline $\begin{array}{l}\text { Threats: Core competencies may be co-opted by the external } \\
\text { environment; emphasis on the risks of exploration }\end{array}$ & $\begin{array}{l}\text { Threats: Core competencies may become rigid; emphasis on the } \\
\text { opportunity costs of failure to explore }\end{array}$ \\
\hline $\begin{array}{l}\text { Governance: Transactions should be standardized for efficiency } \\
\text { and monitored for opportunism }\end{array}$ & $\begin{array}{l}\text { - Governance: Effective norms based on reciprocity can evolve } \\
\text { within relationships }\end{array}$ \\
\hline
\end{tabular}

In sum, strategic renewal represents the processes through which an organization attempts to refresh or renew key attributes, capabilities, or resources. Because employees have a tendency to exploit past competencies rather than explore and develop new ones, successful renewal requires that the organization develop the people, processes, and technologies that foster exploration. Among these three dimensions, the role of people in strategic renewal is the least developed in the literature, but one that is gaining interest (Kang et al., 2007). Viewed through the lens of employee relationships, we see that the unique interactions that occur amongst individual stakeholders may provide opportunities to co-create new opportunities and encourage more exploration. As we explore in the next section, this people-centric, behavioral understanding of strategic renewal also aligns with a management philosophy that has garnered a great deal of interest from both practitioners and academics in recent years-namely, stakeholder relationship management.

\subsection{Stakeholder Relationship Management}

Stakeholder theory argues that organizations create value through their relationships with a range of parties, to include not only shareholders but also customers, suppliers, competitors, employees, regulators, community members, and any other "who can affect or is affected by the achievement of the firm's objectives." (Freeman, 1984, p. 25). Freeman further defines stakeholder relationship management as a process of perspective-taking, understanding the "currencies" or motivations of others, anticipating and giving voice to stakeholder concerns, and seeking positive sum solutions wherein multiple stakeholders benefit simultaneously. Firms that engage in stakeholder relationship management generally allocate resources and decision-making influence beyond those levels necessary to simply maintain the willful participation of the stakeholder (Harrison et al., 2010).

While some have criticized the concept of stakeholder relationship management as too broad, recent treatments have attempted to add more specificity to the approach and to measure the value of its application (see Clement, 2005 for a review). For example, recent examinations point out that interactions among stakeholders have exploratory potential, especially with regard to stimulating innovation, creating demand, and increasing employee engagement (Harrison et al., 2010; Harting, Harmeling, \& Venkataraman, 2006; Jones, 1998; McVea \& Freeman, 2005; Post, Preston, \& Sachs, 2002; Sisodia, Wolfe, \& Sheth, 2007). Others argue that innovation no longer takes place within organizations but rather is distributed across stakeholders in a value network (Bogers $\&$ West, 2012). Scholars have also explored the role of trust in unlocking the value creation potential of stakeholder relationships, enabling exchange partners to move beyond arm's length transactions and build collaborative relationships (e.g., Gulati \& Nickerson, 2008; Lado, Dant, Tekleab, 2008; Jones, 2011; Wicks \& Berman, 2004).

In sum, extant work suggests that stakeholder relationships are valuable not only because they help reduce costs and avoid risk, but also because they create demand, foster flexibility, and attract resources. For these reasons, firms that manage for stakeholders may sustain superior performance as compared with those that do not (Ayuso, Rodríguez, García-Castro, \& Ariño, 2014; Berman, Wicks, Kotha, \& Jones, 1999; Heugens, van den Bosch, \& van Riel, 2002; Waddock \& Graves, 1997). To realize these benefits, firms must develop trusting relationships with stakeholders and understand the stakeholder's perspective. The connections between stakeholder relationship management and strategic renewal remain underexplored, however. In particular, both the strategic renewal and the stakeholder relationship management literatures indicate that employees have an important role to play in ensuring successful outcomes, but relatively few prescriptions have been provided to guide practitioners in their efforts to develop the necessary human capital to achieve these ends (see Kang et al., 2007 for a notable exception). Moreover, no framework yet exists, to our knowledge, which shows how employees engaged in the process of stakeholder relationship management may facilitate strategic renewal as a desired 
outcome. We believe making this connection is important considering the increasing pressures for adaptation, innovation, and change in today's global marketplace.

\section{Theorizing the Stakeholder-Driven Strategic Renewal Framework}

Drawing upon the relational view and behavioral theory, in this section we propose a framework for stakeholder-driven strategic renewal that specifies both how stakeholder relationship management encourages the exploratory activities necessary for strategic renewal and who plays a role in this process.

\subsection{Elaborating the Process of Stakeholder-Driven Strategic Renewal}

We suggest that stakeholder relationship management facilitates strategic renewal in at least three ways: (1) by alerting employees to changing stakeholder needs; (2) by motivating employees to become open to change; and (3) by fostering learning and knowledge assimilation (see Figure 1). We examine these particular mechanisms for two reasons. First, these activities address the primary challenge of strategic renewal, which is to minimize strategic inertia and avoid "the competency trap," which is the tendency to focus on exploiting current competencies at the expense of exploring and developing new ones (e.g., Levinthal \& March, 1993; March, 1991). As we elaborate in this section, these three dimensions of stakeholder relationship management are also particularly important for helping the organization identify and respond to changes in the organizational environment, explore new opportunities, and develop new competencies.

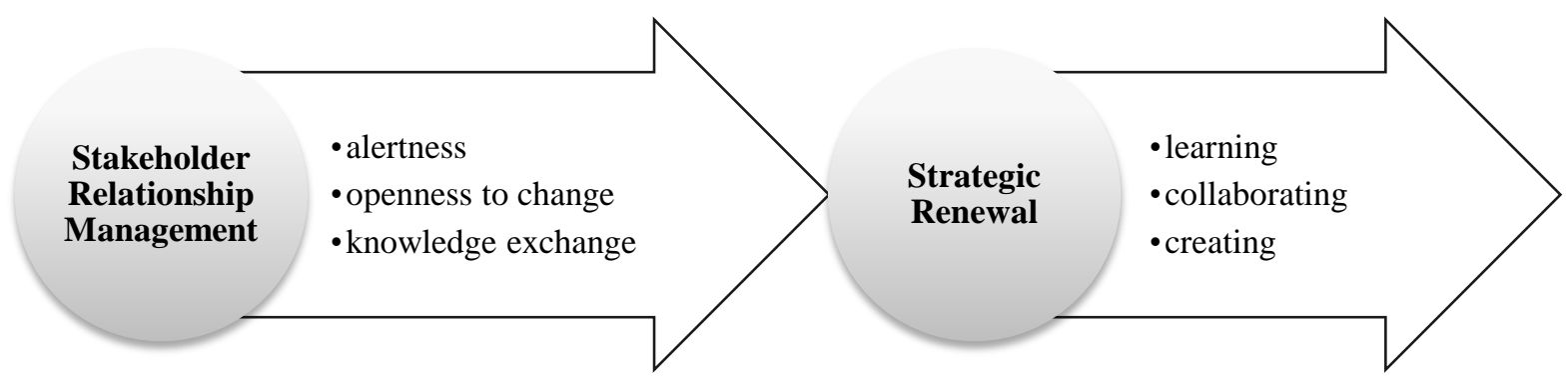

Figure 1. Stakeholder-Driven strategic renewal

\subsubsection{Facilitating Alertness}

One way in which stakeholder relationship management fosters strategic renewal is by alerting employees to changing stakeholder needs. Relationships with external stakeholders may facilitate such alertness in a number of ways. First, these relationships provide informal communication channels whereby external stakeholders may signal the need for change. For instance, suppliers can provide early indications of shifts in technological standards that may ultimately spur renewal efforts. Customers can likewise indicate opportunities for improvement in existing products and services. Moreover, having a personal connection with a stakeholder may also motivate employees to go beyond responding to the stakeholders' current requirements to listen and probe for clues about future needs.

Importantly, this stakeholder approach to environmental alertness offers an alternative to the threat-based logic of other environmental scanning approaches. Whereas Porter (1980) recommends using environmental analysis to alert management to the opportunities created by stakeholder weakness (i.e., a lack of supplier power), the stakeholder relationship management approach may foster employee alertness to a wider array of new opportunities independent of stakeholder power or position. Indeed, Mitchell and colleagues (Mitchell et al., 1997) highlight that one of the behavioral challenges associated with stakeholder relationship management is that executives tend to overemphasize the demands of powerful stakeholders at the expense of marginal or dependent stakeholders, whose needs may be ignored in the short run. Alertness grounded in stakeholder power or salience is also more reactive and unidirectional in nature. In contrast, alertness grounded in the norms of reciprocity that develop among employees in their interactions with stakeholders both powerful and marginal alike (Roloff, 2008) may provide more room for experimentation and collaboration. In short, we argue that stakeholder relationship management facilitates strategic renewal by encouraging employees to become alert to current and future needs of stakeholders, especially those in a marginal power position. 
Proposition 1: Stakeholder relationship management facilitates strategic renewal by alerting employees to changing stakeholder needs.

\subsubsection{Motivating Openness to Change}

Another way that stakeholder relationship management may facilitate strategic renewal is by motivating employees to become open to change. We argue that the social nature of stakeholder relationships provide a powerful antidote to the tendency for employees to impede renewal efforts by avoiding risks and exploiting past competencies (Floyd \& Lane, 2000). In contrast to trading arrangements that follow a "cool and atomistic" arm's length approach designed to minimize opportunism (Uzzi, 1997, p. 36), stakeholder relationships involve loosely structured, personal interactions grounded in norms of reciprocity (Bosse, Phillips, \& Harrison, 2008). Employees participating in these collaborative relationships thus enjoy opportunities to enhance their human and social capital and to imbue their work with a sense of meaning and connection (Sisodia et al., 2007). The emotional appeal of these activities should help employees direct their focus outward and see the benefits of changes that are valued by external stakeholders (Le Ber \& Branzei, 2010).

Note that this openness to change is based not in the recognition of past failures, as is often discussed as an important motivation for change in the renewal literature (e.g., Ariño \& de la Torre, 1998; Simsek et al., 2003), but rather in an awareness of the possibilities that change may bring in the future. As such, we believe that openness to change will develop faster and more easily where it has been motivated by relational concerns as opposed to failure recognition. Stakeholder relationship management thus provides an important counterweight to the natural temptation for risk-averse employees to avoid change by looking inward and making only incremental improvements to the organization's existing capabilities. Stakeholder relationship management instead facilitates strategic renewal by motivating employees to explore, take risks, see the possibilities of change, and adopt an open mindset.

Proposition 2: Stakeholder relationship management facilitates strategic renewal by motivating employees to become open to change.

\subsubsection{Fostering Learning and Knowledge Assimilation}

The information sharing that occurs across organizational boundaries in stakeholder relationship management may also foster two important aspects of strategic renewal-learning and the assimilation of new knowledge. Access to the external knowledge environment is critical, as it is likely to be the source of new knowledge for the firm (DeCarolis \& Deeds, 1999; Powell, Koput, \& Smith-Doerr, 1996). The ability to access such external knowledge, therefore, increases the efficiency with which a firm is able to search and evaluate new strategic alternatives as part of the strategic renewal process (Zahra \& George, 2002). We suggest that relationships with external stakeholders not only connect the focal firm with new knowledge but also that these connections support employees' efforts to learn and assimilate this knowledge (Desai, 2010; Kale, Singh, \& Perlmutter, 2000).

As an example, prior research has found that many pharmaceutical firms access external knowledge environment through the relationships held by their top scientists to stakeholders in the scientific community (Hess \& Rothaermel, 2011; Zucker \& Darby, 1997). Through these relationships, pharmaceutical firms gain access to and share information about the scientific breakthroughs and new methodological approaches that are essential to strategic renewal efforts. In fact, the benefits of this information sharing are so significant that pharmaceutical firms continue to encourage these activities despite the potential losses associated with the disclosure of intellectual property (Henderson \& Cockburn, 1994). Stakeholder relationships are thus critical to strategic renewal, because they represent the primary and most efficient means by which employees can acquire, assimilate, and create new knowledge (Kale et al., 2000; Kang et al., 2007; Kogut \& Zander, 1992; Nahapiet \& Ghoshal, 1998).

Proposition 3: Stakeholder relationship management facilitates strategic renewal by fostering learning and knowledge assimilation.

Thus far, we have investigated the mechanisms by which stakeholder relationship management may be connected to strategic renewal. By synthesizing ideas from relational and behavioral theory, we have elaborated stakeholder-driven strategic renewal as a framework for connecting stakeholder relationship management with core strategic renewal activities including knowledge exchange, learning, collaboration, and creation. An important question remains, however: How can a company optimize these efforts? Certainly not all firms that employ the stakeholder relationship management approach are successful in their efforts. Moreover, firms that manage for stakeholders expose themselves to a number of strategic risks including over-investment in these relationships, employee and stakeholder opportunism, the loss of valuable knowledge assets, and the 
diminishment of core competencies. As shown in Figure 2 and described in the following sections, we explore both the antecedents and limits of stakeholder-driven strategic renewal, identifying when and where this process will be most effective.

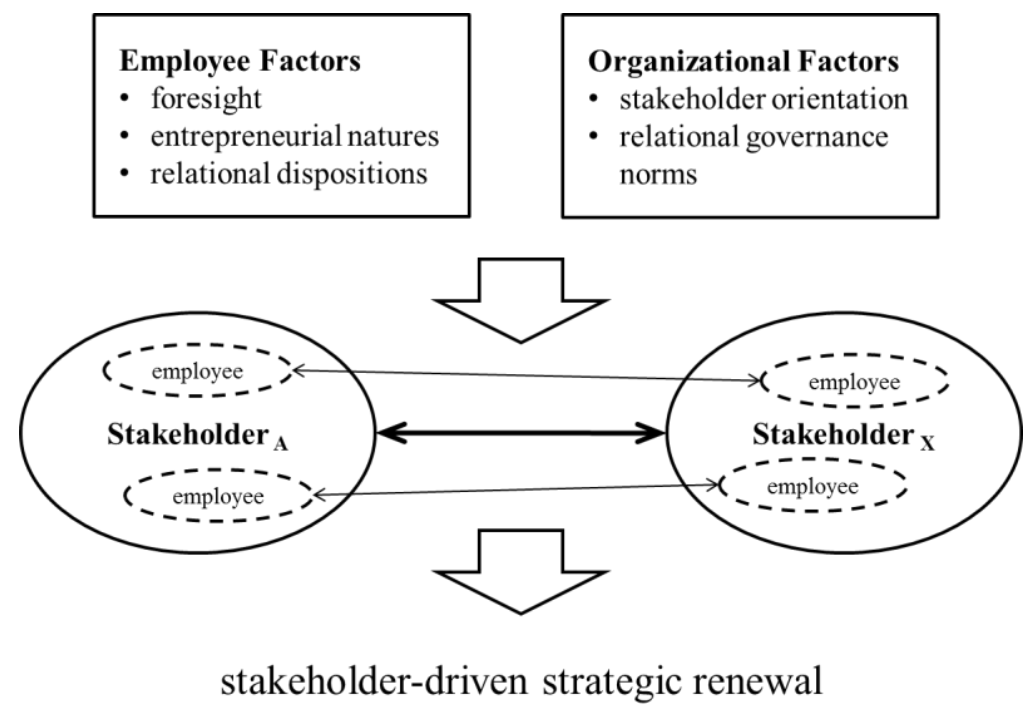

Figure 2. The antecedents of stakeholder-driven strategic renewal

\subsection{The Role of Boundary Spanning Employees in Stakeholder-Driven Strategic Renewal}

The strategic renewal literature focuses on the importance of employees in leadership roles, and certainly organizational leaders set the tone and agenda for both stakeholder relationship management and strategic renewal activities. In practice, however, most interactions with stakeholders are carried out not by leaders but rather by front-line employees. Building on Tushman's idea of boundary spanning individuals (Tushman, 1977; Tushman \& Scanlan, 1981), Freeman labels the employees who interact with external stakeholders "boundary spanning employees" (1984, p. 79). While all of the levels of stakeholder relationship management are important, the most critical-the "bottom line," according to Freeman-is the transactional, because it is through these day to day interactions that the relationship becomes legitimized or delegitimized (1984, p. 69).

Boundary spanning employees may be found at all levels of the organization, from the board of directors to customer service. The nature of their relationship to their organization may be full-time, part-time, or even voluntary. Moreover, a boundary spanning employee may be associated with a range of roles, including sales, public relations, procurement, customer service, technical support, and alliance management. In short, the distinguishing factor of a boundary spanning employee is not his or her level or role but rather the potential for engaging in stakeholder relationship development as an agent of the organization.

Proposition 4: The process of stakeholder-driven strategic renewal is carried out by boundary spanning employees.

In terms of the qualities that boundary spanning employees would need to optimize this process, the strategic renewal literature offers ample guidance. Several scholars have noted the importance of entrepreneurial qualities such as creativity and practical wisdom for strategic renewal (Adner \& Helfat, 2003; Nonaka \& Toyama, 2007; Helfat et al., 2007; Tushman \& Rosenkopf, 1996; Virany, Tushman, \& Romanelli, 1992). Teece (2007, p. 1323) argues that employees need to be able to "see through the fog of uncertainty" to process and filter information from the environment and make predictions about the likely evolution of technologies, latent demand, and marketplace responses.

We add to this list several qualities that might make a boundary spanning employee particularly well suited for building relationships with stakeholders. For instance, Le Ber and Branzei (2010) emphasize the importance of relational attachment in sustaining stakeholder partnerships through initial setbacks. Butterfield and colleagues (Butterfield, Reed, \& Lemak, 2004) also note the importance of personality and inter-personal relations to stakeholder relationship management. In sum, the literature suggests that a stakeholder approach to strategic renewal will be most successful when employees in boundary spanning roles possess foresight, entrepreneurial 
natures, and relational dispositions. In the next section, we dig deeper into this boundary-spanning context to specify how the connections between stakeholder-relationship management activities and strategic renewal work in an ideal state.

Proposition 5: The effectiveness of stakeholder-driven strategic renewal is enhanced when employees in boundary spanning roles possess foresight, entrepreneurial natures, and relational dispositions.

\subsection{The Role of Organizational Context in Stakeholder-Driven Strategic Renewal}

A final, critical element of stakeholder-driven strategic renewal is the organizational context. The ability of boundary spanning employees to capitalize on their dispositions and relational resources to engage in stakeholder-driven strategic renewal also depends, in part, on a supportive work environment. We see two dimensions of the organizational environment as being particularly important for stakeholder-driven strategic renewal effectiveness: The stakeholder orientation of the firm and its relational governance mechanisms.

\subsubsection{Stakeholder Orientation}

Research suggests that organizations may develop an identity or culture with a specific orientation toward stakeholders (Brickson, 2005, 2007; Jones, Felps, \& Bigley, 2007). A stakeholder-oriented culture has been found to affect both employee pro-social behaviors and firm performance (De Luque, Washburn, Waldman, \& House, 2008). We build upon these findings to suggest that having a stakeholder-orientation contributes to stakeholder-driven strategic renewal by fostering norms and decision-making heuristics that motivate employees to engage with stakeholders in ways that are consistent with this identity (Brickson, 2005, 2007; Livengood \& Reger, 2010). Stated formally:

Proposition 6a: The effectiveness of stakeholder-driven strategic renewal is enhanced by a stakeholder orientation at the focal firm level.

We further propose that where this stakeholder-oriented organizational identity is shared and reciprocated by trading partners, the process of stakeholder-driven strategic renewal will be further enhanced. Indeed, studies show that many alliance relationships fail due to divergent organizational identities and control mechanisms, which make employee interactions more challenging (e.g., Lorenzoni \& Lipparini, 1999). On the other hand, where organizational identities supporting stakeholder-oriented activities converge, employees will be further motivated to engage in activities that facilitate the sensing and shaping of opportunity and less likely to encounter obstacles to such collaborative efforts.

Proposition 6b: Stakeholder orientations at the focal firm and the partner firm are complements such that the effectiveness of stakeholder-driven strategic renewal is further enhanced when boundary spanning employees of firms with these orientations interact.

\subsubsection{Relational Governance Norms}

In addition to stakeholder orientation, relational governance mechanisms also provide explicit information about how employees should (and should not) engage with stakeholders. A great deal of research at both the individual and alliance levels has explored the effects of control systems and other governance mechanisms. Briefly summarizing the extant literature, research shows that in order to reap the rewards of collaboration and innovation, employees also need the freedom and flexibility to take risks and experiment (Doz, 1996; Uzzi, 1996, 1997). A heavy contracting and monitoring focus, on the other hand, may inhibit learning and innovation (Ariño \& de la Torre, 1998; Levinthal \& March, 1993; McGrath, 2001), and may interfere with the development of norms of cooperation, altruism, and reciprocity (Bosse et al., 2008; Larson, 1992). In short, if we expect the worst of employees and assume that actors will behave in purely self-interested or opportunistic fashion, it is not surprising that people condition their behavior to live up to these expectations (Ghoshal \& Moran, 1996).

Of course, some monitoring activities are part of the normal course of business and cannot be avoided. It would be a rare to find modern businesses doing away with supplier contracts, customer invoices, inventory reconciliations, and so forth. However, where the employee's role includes creative tasks, such as in product design or research and development, we recommend that employees be given the autonomy to develop relationship-specific norms and thus reap the benefits of stakeholder-driven strategic renewal. For example, firms may allow some employees the freedom and flexibility to determine how they will measure success and to determine the appropriate norms of behavior in their relationships. These actions not only encourage distributive and procedural justice (Bosse et al., 2008), such activities also signal trust, thus increasing both parties' ability to think creatively and to minimize the need for expensive monitoring activities (Dyer \& Chu, 2003; Lado, Dant, \& Tekleab, 2008; Zaheer, McEvily, \& Perrone, 1998). 
Proposition 7: A contracting and monitoring approach to relational governance inhibits stakeholder-driven strategic renewal.

\subsection{The Limits of Stakeholder-Driven Strategic Renewal}

Despite the many beneficial outcomes associated with stakeholder-driven strategic renewal, this approach is not without its limitations. Organizations may suffer if employees begin to privilege external stakeholder needs above company concerns and "give away the store" (Harrison \& Bosse, 2013). Even worse, opportunistic employees might leverage their close ties outside of the organization to initiate collusive arrangements for self-gain (Cennamo, Berrone, \& Gomez-Mejia, 2009). Knowledge-based firms might also incur transfer problems whereby information sharing with external stakeholders diminishes the strategic value of their core knowledge assets (Ndofor \& Levitas, 2004). In addition, the relational assets generated by long-lived or close relationships between employees and stakeholders may be difficult to replicate and thus vulnerable to employee absenteeism, turnover, or attrition. Scholars have further noted that the outcomes of stakeholder relationship management may be constrained by a lack of resources or skills (Reynolds, Schultz, \& Hekman, 2006).

The more likely downside of stakeholder-driven strategic renewal, however, is the diminishment of capability effectiveness, especially those related to the capacity to exploit or seize opportunities (Teece, 2007). Opportunity exploitation refers to the internal activities related to commercialization whereby the firm transforms tacit knowledge into repeatable and stable practices, often by means of a manual, tool, or heuristic (Nonaka, 1994; Zander \& Kogut, 1995). External stakeholders sometimes support these exploitation activities-for instance, suppliers may provide the inputs to production-but the focus of seizing and commercializing opportunities remains largely internal to the firm. Employees that devote too much time and energy to external stakeholder relationship development may impede these internally-focused efforts by avoiding the important, but less socially rewarding, tasks of translating new ideas into executable business strategies and monitoring the effectiveness of these plans.

In sum, we propose that the benefits of stakeholder-driven strategic renewal will exhibit total diminishing returns. As shown in Figure 3, firms experiencing a misfit between employee dispositions and boundary spanning roles and/or firms that do not create the right organizational environment for stakeholder relationship management risk privileging internal technical capability development (seizing) at the expense of organizational dynamism (sensing and shaping) (Teece, 2007). Such insulation may protect the technological core of the organization from competitive threats (Thompson, 1967), but this disconnectedness will harm the exploratory efforts of the organization and create resistance to strategic renewal. At the other extreme, an organization can over-invest in stakeholder relationships and foster engagement at the expense of execution, thus impeding the development of commercial capabilities and risking the loss of core competencies and competitive advantages. In short, developing stakeholder-driven strategic renewal into an organizational level capability involves a delicate balance between protecting core competencies while simultaneously opening up pathways for new innovations.

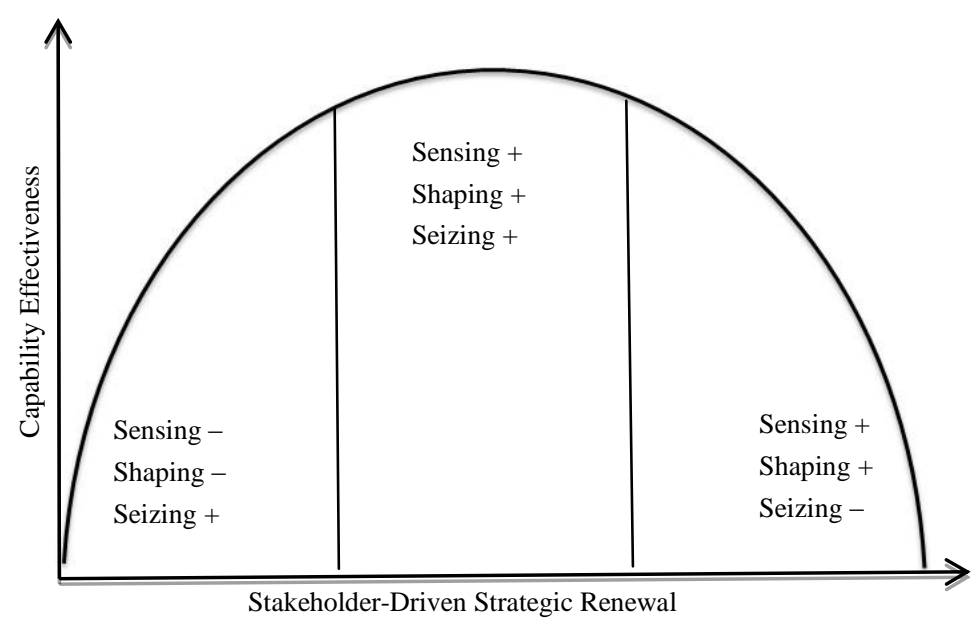

Figure 3. The limits of stakeholder-driven strategic renewal 


\section{Discussion}

In this paper, we have explored the ways in which stakeholder relationships may become valuable pathways for strategic renewal. We have described stakeholder-driven strategic renewal as a process of alertness, openness to change, and knowledge exchange that facilitates the core strategic renewal activities of learning, collaborating, and creating opportunities in the organizational environment. We have also explored the boundary conditions of this process by elaborating how it will be most effective where boundary spanning employees possessing foresight, entrepreneurial natures, and relational dispositions are working within and across organizations with stakeholder-oriented cultures and relational governance norms.

By unpacking the connections between stakeholder relationship management and strategic renewal and further identifying the limits of this approach to renewal, this paper makes several theoretical contributions. First, we contribute to the management literature by illuminating the mechanisms by which stakeholder relationship management activities foster strategic renewal. Our framework suggests that the relational activities of stakeholder management only result in opportunity identification and development, but they also help overcome the tendency to exploit past competencies by motivating managers to explore, to become open to change, and to capture new knowledge. Second, this examination brings much needed attention to the role of employees in this process (Butterfield et al., 2004; Kang et al., 2007; Lubatkin et al., 2006; Woodworth, 1986; Zakhem, 2008). In particular, our analysis suggests the importance of considering relational capabilities when placing employees in boundary-spanning positions where interactions with external stakeholders are most likely. Finally, we complement past work exploring the strategic potential of stakeholder relationship management (e.g., Harrison et al., 2010) while also offering a more reciprocal approach (e.g., Post et al., 2002) that de-emphasizes the demands of powerful stakeholders to also facilitate inputs from marginal stakeholders that may provide important opportunities in the long-run (Roloff, 2008).

Considering the substantial benefits of stakeholder relationships and their potential for creating competitive advantages, it begs the question, why do so many organizations fail to realize these outcomes (e.g., Shropshire \& Hillman, 2007)? Other scholars have argued that relationship outcomes are constrained by a lack of resources or skills (Reynolds et al., 2006), differences in strategic position and power (Eisenhardt \& Schoonhoven, 1996), and the time needed to establish trust (Harrison et al., 2010). While these factors are certainly important, we argue that the stakeholder-driven strategic renewal framework as elaborated here helps to explain variation in alliance and partnership outcomes in ways that traditional resource dependency and transaction cost views cannot. Instead of emphasizing the inputs to the interaction, the stakeholder-driven strategic renewal framework focuses on the process of relating itself and the dispositions of the actors involved in this interaction. This change in emphasis is not to say that inputs of time, money, and other resources do not matter, but rather that they may not matter as much as previously thought. We propose that everyday employee interactions can become a relatively low cost but invaluable source of insights into stakeholder needs and changes in the organizational environment, an impetus for change, and a conduit for learning and knowledge acquisition. Furthermore, the relational rents accruing to organizations that foster stakeholder-driven strategic renewal may be mutually reinforcing and rise exponentially with the number of stakeholders adopting a similar approach. As these relational rents are difficult to imitate, they are likely to be a source of competitive advantage for the firm (Barney, 1986; Harting et al., 2006; Ireland, Hitt, \& Vaidyanath, 2002). At the same time, we recognize that there are limits to the benefits of stakeholder-driven strategic renewal. Employees may over-invest in stakeholder relationships, may leverage these relationships for self-gain, neglect commercialization efforts, and/or expose the core competencies of the organization to opportunistic competitors. Future research may further explore the strategies enacted by firms to balance these trade-offs and to specify the limits of this approach.

\subsection{Examples of Stakeholder-Driven Strategic Renewal}

A number of examples of stakeholder-driven strategic renewal have emerged in recent years. Whole Foods Market fosters alertness to customer needs by engaging in supplier-driven strategic renewal. Unlike most retailers, which select suppliers based on criteria such as reputation or ability to pay slotting fees, Whole Foods gives away shelf space to its potential suppliers for a trial period and lets its customers determine whether or not to carry the new product. At the end of the trial, Whole Foods gives the supplier a detailed report about what customers liked along with suggested price points and product improvement areas. This fast-moving, experimental, and information intensive approach to stakeholder relationship management ensures that Whole Foods' managers are sensitive to local buying trends, aware of changes in customers' preferences, open to feedback, and responsive to the needs of both customers and suppliers. In these ways, stakeholder relationship management helps Whole Foods sense opportunities for change and engage in strategic renewal from the bottom up. 
Another example of stakeholder-driven strategic renewal comes from the pharmaceutical industry. Firms such as Merck engage in community-driven strategic renewal by encouraging their top scientists to publish with other researchers and to share their findings with the broader scientific community through seminars and conferences. These relationships with stakeholders in the scientific community enable strategic renewal by fostering information sharing about scientific breakthroughs and new methodological approaches. Yet another example of stakeholder-driven strategic renewal may be found in manufacturing. Honda engages in employee-driven strategic renewal by instituting waigawa-a temporary suspension of the protocols of social hierarchy-to encourage employees at all levels of the organization to share their suggestions and ideas for change (Sisodia et al., 2007). Future empirical studies of stakeholder-driven strategic renewal may uncover many more examples of how firms leverage stakeholder relationship management to engage in both incremental and transformative strategic renewal.

\section{Conclusion}

Recognizing the complex environment from which stakeholder relationships develop and the variance among the actors that give them life, it seems likely that there will be a great deal of heterogeneity in stakeholder-driven strategic renewal activities. Additional studies are needed to further operationalize the framework and to unpack questions such as: How much of the success of stakeholder-driven strategic renewal is informed by employee factors? To what extent is success affected by the organizational context? Other scholars have posited that reciprocal relationships are more likely among organizations in fast-moving industries, in situations where organizations need to exchange tacit information and skills, or when reciprocal coordination needs are high (Powell, 1990; Thompson, 1967). What we may find is that stakeholder-driven strategic renewal is more successful for firms operating in these contexts. Alternately, we may find that environmental conditions are less important, and that renewal naturally develops from stakeholder relationship management due to the quality of interactions between and among employees and external stakeholders over time. If this alternate explanation holds true, then the stakeholder-driven strategic renewal perspective may shed new light on the age old debate of which stakeholders have legitimacy (e.g., Mitchell et al., 1997; Phillips, 2003) by redefining legitimacy as a quality attributed to particular relationships rather than heterogeneous categorizations of stakeholder.

The stakeholder-driven strategic renewal approach challenges us to look more carefully at the nature of stakeholder interactions and to recognize the inherent value of these relationships. When we consider stakeholder relationships from the perspective of the individual actors that give them life, we see that these interactions are a previously under-appreciated resource that may prove critical to renewal efforts. Not only does the social nature of stakeholder relationship management help minimize the negative effects of behavioral limitations that lead to strategic inertia, but the norms of reciprocity that guide such relationships foster strategic renewal from the bottom up.

\section{Acknowledgments}

The authors wish to thank Jeff Harrison, Adelaide Wilcox-King, David Hart, Ed Freeman, and participants at the 2010 Stakeholder Conference at Solitude and the 2011 Academy of Management Conference for their feedback on an earlier version of this article.

\section{References}

Adner, R., \& Helfat, C. E. (2003). Corporate effects and dynamic managerial capabilities. Strategic Management Journal. http://dx.doi.org/10.1002/smj.331

Agarwal, R., \& Helfat, C. E. (2009). Strategic renewal of organizations. Organization Science. http://dx.doi.org/10.1287/orsc.1090.0423

Agle, B. R., Donaldson, T., Freeman, R. E., Jensen, M. C., Mitchell, R. K., \& Wood, D. J. (2008). Dialogue: Toward superior stakeholder theory. Business Ethics Quarterly. http://dx.doi.org/10.5840/beq200818214

Ariño, A., \& De la Torre, J. (1998). Learning from failure: Towards an evolutionary model of collaborative ventures. Organization Science. http://dx.doi.org/10.1287/orsc.9.3.306

Ayuso, S., Rodríguez, M. A., García-Castro, R., \& Ariño, M. A. (2014). Maximizing Stakeholders' Interests An Empirical Analysis of the Stakeholder Approach to Corporate Governance. Business \& Society. http://dx.doi.org/10.1177/0007650311433122

Barney, J. (1986). Strategic factor markets: Expectations, luck, and business strategy. Management Science. http://dx.doi.org/10.1287/mnsc.32.10.1231

Bateman, T. S., \& Zeithaml, C. P. (1989). The psychological context of strategic decisions: A model and 
convergent findings. Strategic Management Journal. http://dx.doi.org/10.1002/smj.4250100106

Berman, S. L., Wicks, A. C., Kotha, S., \& Jones T. M. (1999). Does stakeholder orientation matter? The relationship between stakeholder management models and firm financial performance. Academy of Management Journal. http://dx.doi.org/10.2307/256972

Bogers, M., \& West, J. (2012). Managing distributed innovation: Strategic utilization of open and user innovation. Creativity and innovation management. http://dx.doi.org/10.1111/j.1467-8691.2011.00622.x

Bosse, D. A., Phillips, R. A., \& Harrison, J. S. (2008). Stakeholders, reciprocity, and firm performance. Strategic Management Journal. http://dx.doi.org/10.1002/smj.743

Brickson, S. L. (2005). Organizational identity orientation: Forging a link between organizational identity and organizations' relations with stakeholders. Administrative Science Quarterly, 50(4), 576-609.

Brickson, S. L. (2007). Organizational identity orientation: The genesis of the role of the firm and distinct forms of social value. Academy of Management Review. http://dx.doi.org/10.5465/AMR.2007.25275679

Butterfield, K. D., Reed, R., \& Lemak, D. J. (2004). An inductive model of collaboration from the stakeholder's perspective. Business \& Society. http://dx.doi.org/10.1177/0007650304265956

Cennamo, C., Berrone, \& Gomez-Mejia, L. R. (2009). Does stakeholder management have a dark side? Journal of Business Ethics. http://dx.doi.org/10.1007/s10551-008-0012-x

Clement, R. W. (2005). The lessons from stakeholder theory for US business leaders. Business Horizons. http://dx.doi.org/10.1016/j.bushor.2004.11.003

Crossan, M. M., \& Berdrow, I. (2003). Organizational learning and strategic renewal. Strategic Management Journal. http://dx.doi.org/10.1002/smj.342

Cyert, R. M., \& March, J. G. (1963). A Behavioral Theory of the Firm. Malden, MA: Wiley-Blackwell.

DeCarolis, D. M., \& Deeds, D. L. (1999). The impact of stocks and flows of organizational knowledge on firm performance: An empirical investigation of the biotechnology industry. Strategic Management Journal. http://dx.doi.org/10.1002/(SICI)1097-0266(199910)20:10\%3C953::AID-SMJ59\%3E3.0.CO;2-3

De Luque, M. S., Washburn, N. T., Waldman, D. A., \& House, R. J. (2008). Unrequited profit: How stakeholder and economic values relate to subordinates' perceptions of leadership and firm performance. Administrative Science Quarterly. http://dx.doi.org/10.2189/asqu.53.4.626

Desai, V. M. (2010). Power, legitimacy, and urgency in organizational learning: Learning through stakeholder complaints to improve quality in the California nursing home industry. Journal of Leadership \& Organizational Studies. http://dx.doi.org/10.1177/1548051810368543

Doz, Y. L. (1996). The evolution of cooperation in strategic alliances: Initial conditions or learning processes. Strategic Management Journal. http://dx.doi.org/10.1002/smj.4250171006

Dyer, J. H., \& Singh, H. (1998). The relational view: Cooperative strategy and sources of interorganizational competitive advantage. Academy of Management Review. http://dx.doi.org/10.2307/259056

Dyer, J. H., \& Chu, W. (2003). The role of trustworthiness in reducing transaction costs and improving performance: Empirical evidence from the United States, Japan, and Korea. Organization Science. http://dx.doi.org/10.1287/orsc.14.1.57.12806

Eisenhardt, K. M., \& Schoonhoven, C. B. (1996). Resource-based view of strategic alliance formation: Strategic and social effects in entrepreneurial firms. Organization Science. http://dx.doi.org/10.1287/orsc.7.2.136

Floyd, S. W., \& Lane, J. (2000). Strategizing throughout the organization: Managing role conflict in strategic renewal. Academy of Management Review. http://dx.doi.org/10.5465/AMR.2000.2791608

Freeman, R. E. (1984). Strategic Management: A Stakeholder Approach. Boston, MA: Pitman.

Freeman, R. E., Harrison, J. S., \& Wicks, A. C. (2007). Managing for Stakeholders: Survival, Reputation, and Success. Princeton, NJ: Yale University Press.

Ghoshal, S., \& Moran, P. (1996). Bad for practice: A critique of the transaction cost theory. Academy of Management Review. http://dx.doi.org/10.5465/AMR.1996.9602161563

Gulati, R., \& Nickerson, J. A. (2008). Interorganizational trust, governance choice, and exchange performance. Organization Science. http://dx.doi.org/10.1287/orsc.1070.0345 
Harrison, J. S., Bosse, D. A., \& Phillips, R. A. (2010). Managing for stakeholders, stakeholder utility functions, and competitive advantage. Strategic Management Journal. http://dx.doi.org/10.1002/smj.801

Harrison, J. S., \& Bosse, D. A. (2013). How much is too much? The limits to generous treatment of stakeholders. Business Horizons. http://dx.doi.org/10.1016/j.bushor.2013.01.014

Harting, T. R., Harmeling, S. S., \& Venkataraman, S. (2006). Innovative stakeholder relations: When "ethics pays" (and when it doesn't). Business Ethics Quarterly. http://dx.doi.org/10.5840/beq20061612

He, Z. L., \& Wong, K. (2004). Exploration vs. exploitation: An empirical test of the ambidexterity hypothesis. Organization Science. http://dx.doi.org/10.1287/orsc.1040.0078

Helfat, C. E., Finkelstein, S., Mitchell, W., Peteraf, M. A., Singh, H., Teece, D. J., \& Winter, S. G. (2007). Dynamic Capabilities. Malden, MA: Blackwell Publishing.

Henderson, R., \& Cockburn, I. (1994). Measuring competence? Exploring firm effects in pharmaceutical research. Strategic Management Journal. http://dx.doi.org/10.1002/smj.4250150906

Hess, A. M., \& Rothaermel, F. T. (2011). When are assets complementary? Star scientists, strategic alliances, and innovation in the pharmaceutical industry. Strategic Management Journal. http://dx.doi.org/10.1002/smj.916

Heugens, P., Van den Bosch, F. A., \& Van Riel, C. B. (2002). Stakeholder integration building mutually enforcing relationships. Business \& Society. http://dx.doi.org/10.1177/000765030204100104

Huff, J. O., Huff, A. S., \& Thomas, H. (1992). Strategic renewal and the interaction of cumulative stress and inertia. Strategic Management Journal. http://dx.doi.org/10.1002/smj.4250131006

Ireland, R. D., Hitt, M. A., \& Vaidyanath, D. (2002). Alliance management as a source of competitive advantage. Journal of Management. http://dx.doi.org/10.1177/014920630202800308

Johnson, G. (1988). Rethinking incrementalism. Strategic Management Journal. http://dx.doi.org/10.1002/smj.4250090107

Jones, O. (1998). From maturity to entrepreneurship: A stakeholder model of innovation. Creativity and Innovation Management. http://dx.doi.org/10.1111/1467-8691.00095

Jones, T. M., Felps, W., \& Bigley, G. A. (2007). Ethical theory and stakeholder-related decisions: The role of stakeholder culture. Academy of Management Review. http://dx.doi.org/10.5465/AMR.2007.23463924

Jones, T. M. (2011). The nature of firm-stakeholder relationships: Realizing the potential of an underappreciated contribution of Freeman's 25-year old classic. In R. Phillips (Ed), Stakeholder Theory: Impact and Prospects(pp. 54-75). Northampton, MA: Edward Elgar Publishing.

Kale, P., Singh, H., \& Perlmutter, H. (2000). Learning and protection of proprietary assets in strategic alliances: Building relational capital. Strategic Management Journal. http://dx.doi.org/10.1002/(SICI)1097-0266(200003)21:3\%3C217::AID-SMJ95\%3E3.3.CO;2-P

Kang, S. C., Morris, S. S., \& Snell, S. A. (2007). Relational archetypes, organizational learning, and value creation: Extending the human resource architecture. Academy of Management Review. http://dx.doi.org/10.5465/AMR.2007.23464060

Kogut, B., \& Zander, U. (1992). Knowledge of the firm, combinative capabilities and the replication of technology. Organization Science. http://dx.doi.org/10.1287/orsc.3.3.383

Kuratko, D. F., Hornsby, J. S., \& Goldsby, M. G. (2007). The relationship of stakeholder salience, organizational posture, and entrepreneurial intensity to corporate entrepreneurship. Journal of Leadership \& Organizational Studies. http://dx.doi.org/10.1177/10717919070130040801

Lado, A. A., Dant, R. R., \& Tekleab, A. G. (2008). Trust, opportunism paradox, relationalism, and performance in interfirm relationships: Evidence from the retail industry. Strategic Management Journal. http://dx.doi.org/10.1002/smj.667

Larson, A. (1992). Network dyads in entrepreneurial settings: A study of the governance of exchange relationships. Administrative Science Quarterly. http://dx.doi.org/10.2307/2393534

Le Ber, M. J., \& Branzei, O. (2010). (Re)Forming Strategic Cross-Sector Partnerships Relational Processes of Social Innovation. Business \& Society. http://dx.doi.org/10.1177/0007650309345457

Levinthal, D. A., \& March, J. (1993). The myopia of learning. Strategic Management Journal. 
http://dx.doi.org/10.1002/smj.4250141009

Livengood, R. S., \& Reger, R. K. (2010). That's our turf! Identity domains and competitive dynamics. Academy of Management Review. http://dx.doi.org/10.5465/AMR.2010.45577794

Lorenzoni, G., \& Lipparini, A. (1999). The leveraging of interfirm relationships as a distinctive organizational capability: A longitudinal study. Strategic Management Journal. http://dx.doi.org/10.1002/(SICI)1097-0266(199904)20:4\%3C317::AID-SMJ28\%3E3.0.CO;2-3

Lubatkin, M. H., Simsek, Z., Ling, Y., \& Veiga, J. F. (2006). Ambidexterity and performance in small-to medium-sized firms: The pivotal role of top management team behavioral integration. Journal of Management. http://dx.doi.org/10.1177/0149206306290712

March, J. G., \& Shapira, Z. (1987). Managerial perspectives on risk and risk taking. Management Science. http://dx.doi.org/10.1287/mnsc.33.11.1404

March, J. G. (1991). Exploration and exploitation in organizational learning. Organization Science. http://dx.doi.org/10.1287/orsc.2.1.71

McGrath, R. G. (2001). Exploratory learning, innovative capacity and managerial oversight. Academy of Management Journal. http://dx.doi.org/10.2307/3069340

McVea, J. F., \& Freeman, R. E. (2005). A names-and-faces approach to stakeholder management: How focusing on stakeholders as individuals can bring ethics and entrepreneurial strategy together. Journal of Management Inquiry. http://dx.doi.org/10.1177/1056492604270799

Mitchell, R. K., Agle, B. R., \& Wood, D. J. (1997). Toward a theory of stakeholder identification and salience: Defining the principle of who and what really counts. Academy of Management Review. http://dx.doi.org/10.5465/AMR.1997.9711022105

Nahapiet, J., \& Ghoshal, S. (1998). Social capital, intellectual capital, and the organizational advantage. Academy of Management Review. http://dx.doi.org/10.5465/AMR.1998.533225

Ndofor, H. A., \& Levitas, E. (2004). Signaling the strategic value of knowledge. Journal of Management. http://dx.doi.org/10.1016/j.jm.2004.04.002

Nonaka, I. (1994). A dynamic theory of knowledge creation. Organization Science. http://dx.doi.org/10.1287/orsc.5.1.14

Nonaka, I., \& Toyama, R. (2007). Strategic management as distributed practical wisdom (phronesis). Industrial and Corporate Change. http://dx.doi.org/10.1093/icc/dtm014

O’Reilly III, C. A., \& Tushman, M. L. (2008). Ambidexterity as a dynamic capability: Resolving the innovator's dilemma. Research in Organizational Behavior. http://dx.doi.org/10.1016/j.riob.2008.06.002

Phillips, R. (2003). Stakeholder legitimacy. Business Ethics Quarterly. http://dx.doi.org/10.5840/beq20031312

Porter, M. (1980). Competitive Strategies. New York: Free Press.

Post, J. E., Preston, L. E., \& Sachs, S. (2002). Managing the extended enterprise. California Management Review. http://dx.doi.org/10.2307/41166151

Powell, W. W. (1990). Neither market nor hierarchy: Network forms of organization. In B. M. Staw, \& L. L. Cummings (Eds.), Research in Organizational Behavior (pp. 295-336). Greenwich, CT: JAI Press.

Powell, W. W., Koput, K. W., \& Smith-Doerr, L. (1996). Interorganizational collaboration and the locus of innovation: Networks of learning in biotechnology. Administrative Science Quarterly. http://dx.doi.org/10.2307/2393988

Reynolds, S. J., Schultz, F. C., \& Hekman, D. R. (2006). Stakeholder theory and managerial decision-making: Constraints and implications of balancing stakeholder interests. Journal of Business Ethics. http://dx.doi.org/10.1007/s10551-005-5493-2

Roloff, J. (2008). Learning from multi-stakeholder networks: Issue-focused stakeholder management. Journal of Business Ethics. http://dx.doi.org/10.1007/s10551-007-9573-3

Shropshire, C., \& Hillman, A. J. (2007). A longitudinal study of significant change in stakeholder management. Business \& Society. http://dx.doi.org/10.1177/0007650306295753

Simsek, Z., Lubatkin, M. H., \& Floyd, S. W. (2003). Inter-firm networks and entrepreneurial behavior: A structural embeddedness perspective. Journal of Management. 
http://dx.doi.org/10.1016/S0149-2063(03)00018-7

Sisodia, R., Wolfe, D. B., \& Sheth, J. N. (2007). Firms of Endearment: How World-Class Companies Profit from Passion and Purpose. New Jersey: Wharton School Publishing.

Smith, W. K., \& Tushman, M. L. (2005). Managing strategic contradictions: A top management model for managing innovation streams. Organization Science. http://dx.doi.org/10.1287/orsc.1050.0134

Staw, B. M., Sandelands, L. E., \& Dutton, J. E. (1981). Threat rigidity effects in organizational behavior: A multilevel analysis. Administrative Science Quarterly. http://dx.doi.org/10.2307/2392337

Staw, B. M. (1981). The escalation of commitment to a course of action. Academy of Management Review. http://dx.doi.org/10.5465/AMR.1981.4285694

Teece, D. J. (2007). Explicating dynamic capabilities: The nature and microfoundations of (sustainable) enterprise performance. Strategic Management Journal. http://dx.doi.org/10.1002/smj.640

Thompson, J. D. (1967). Organizations in Action: Social Science Bases of Administrative Theory. Edison, NJ: Transaction Publishers.

Tushman, M. L. (1977). Special boundary roles in the innovation process. Administrative Science Quarterly. http://dx.doi.org/10.2307/2392402

Tushman, M. L., \& Scanlan, T. J. (1981). Boundary spanning individuals: Their role in information transfer and their antecedents. Academy of Management Journal. http://dx.doi.org/10.2307/255842

Tushman, M. L., \& O'Reilly, C. (1996). The ambidextrous organization: Managing evolutionary and revolutionary change. California Management Review. http://dx.doi.org/10.2307/41165852

Tushman, M. L., \& Rosenkopf, L. (1996). Executive succession, strategic reorientation and performance growth: A longitudinal study in the US cement industry. Management Science. http://dx.doi.org/10.1287/mnsc.42.7.939

Tushman, M. L., Smith, W. K., Wood, R. C., Westerman, G., \& O'Reilly, C. (2010). Organizational designs and innovation streams. Industrial and Corporate Change. http://dx.doi.org/10.1093/icc/dtq040

Uzzi, B. (1996). The sources and consequences of embeddedness for the economic performance of organizations: The network effect. American Sociological Review. http://dx.doi.org/10.2307/2096399

Uzzi, B. (1997). Social structure and competition in interfirm networks: The paradox of embeddedness. Administrative Science Quarterly. http://dx.doi.org/10.2307/2393808

Virany, B., Tushman, M. L., \& Romanelli, E. (1992). Executive succession and organization outcomes in turbulent environments: An organization learning approach. Organization Science. http://dx.doi.org/10.1287/orsc.3.1.72

Waddock, S. A., \& Graves, S. B. (1997). The corporate social performance-financial performance link. Strategic Management

Journal. http://dx.doi.org/10.1002/(SICI)1097-0266(199704)18:4\%3C303::AID-SMJ869\%3E3.0.CO;2-G

Walsh, J. P. (1995). Managerial and organizational cognition: Notes from a trip down memory lane. Organization Science. http://dx.doi.org/10.1287/orsc.6.3.280

Woodworth, W. P. (1986). Managing from below. Journal of Management. http://dx.doi.org/10.1177/014920638601200307

Wicks, A. C., \& Berman, S. L. (2004). The effects of context of trust in firm-stakeholder relationships: The institutional environment, trust creation, and firm performance. Business Ethics Quarterly. http://dx.doi.org/10.5840/beq20041411

Zaheer, A., McEvily, B., \& Perrone, V. (1998). Does trust matter? Exploring the effects of interorganizational and interpersonal trust on performance. Organization Science. http://dx.doi.org/10.1287/orsc.9.2.141

Zahra, S. A., \& George, G. (2002). Absorptive capacity: A review, reconceptualization, and extension. Academy of Management Review. http://dx.doi.org/10.5465/AMR.2002.6587995

Zakhem, A. (2008). Stakeholder management capability: A discourse-theoretical approach. Journal of Business Ethics. http://dx.doi.org/10.1007/s10551-007-9405-5

Zander, U., \& Kogut, B. (1995). Knowledge and the speed of the transfer and imitation of organizational capabilities: An empirical test. Organization Science. http://dx.doi.org/10.1287/orsc.6.1.76 
Zucker, L. G., \& Darby, M. R. (1997). Present at the biotechnological revolution: Transformation of technological identity for a large incumbent pharmaceutical firm. Research Policy. http://dx.doi.org/10.1016/S0048-7333(97)00017-6

\section{Copyrights}

Copyright for this article is retained by the author(s), with first publication rights granted to the journal.

This is an open-access article distributed under the terms and conditions of the Creative Commons Attribution license (http://creativecommons.org/licenses/by/3.0/). 